\title{
Elimination of mother-to-child transmission of HIV in Oman: a success story from the Middle East
}

\author{
Ali Elgalib, ${ }^{1}$ Fatma Al-Hinai, ${ }^{2}$ Jamila Al-Abri, ${ }^{2}$ Samir Shah, ${ }^{1}$ Zeyana Al-Habsi, ${ }^{1}$ Maha Al-Fouri, ${ }^{1}$ Richard Lau, ${ }^{1}$ Hanan Al-Kindi, ${ }^{1}$ Adil Al-Wahaibi, ${ }^{1}$ Amal Al- \\ Maani, ${ }^{1,3}$ Bader Al-Rawahi, ${ }^{1}$ Said Al-Lamki ${ }^{2}$ and Seif Al-Abri ${ }^{1}$
}

${ }^{1}$ Directorate General for Disease Surveillance and Control, Ministry of Health, Muscat, Oman (Correspondence to: A. Elgalib: alielgalib@yahoo.co.uk). ${ }^{2}$ Directorate General of Primary Health Care, Ministry of Health, Muscat, Oman. ${ }^{3}$ Child Health Department, Royal Hospital, Muscat, Oman.

\begin{abstract}
Background: In January 2016, the National AIDS Programme (NAP) in Oman introduced a package of interventions, including capacity building for service providers, to improve the quality of HIV services.

Aims: To report the impact of these interventions on the rate of vertical HIV transmission in the period from January 2016 to December 2019. We also describe the virological and obstetric outcomes for HIV-infected pregnant women.

Methods: This was a medical record review of 94 HIV-positive pregnant women (median age 32 years; interquartile range 25-34 years) reported to NAP in 2016-2019.

Results: There were 110 pregnancies in 94 women. The majority $(75.3 \%, 61 / 81)$ of women were diagnosed with HIV infection from routine antenatal screening, with $60 \%$ (66/110) of pregnancies occurring in women who knew their HIV status at conception. Caesarean section was the most common (50\%) mode of delivery. The preterm labour and low birth weight rates were $21.2 \%$ and $15.9 \%$, respectively. The antiretroviral coverage during pregnancy was $95.5 \%$, with most $(87.8 \%)$ women reporting excellent or good adherence. The majority $(81.6 \%)$ of women achieved HIV viral load of $<400$ copies $/ \mathrm{ml}$ at or near delivery. Almost all infants (99\%) were given prophylactic antiretrovirals. The rate of mother-to-child transmission of HIV was $1 \%$.

Conclusion: The obstetric and virological outcomes for HIV-infected pregnant women delivered in 2016-2019 were favourable, with a low rate of mother-to-child transmission of HIV. Oman is now in the process of finalizing application of World Health Organization validation of elimination of mother-to-child transmission of HIV.
\end{abstract}

Keywords: elimination, HIV/AIDS, mother-to-child transmission, Middle East, Oman

Citation: Elgalib A; Al-Hinai F; Al-Abri J; Shah S; Al-Habsi Z; Al-Fouri M; et al. Elimination of mother-to-child transmission of HIV in Oman: a success story from the Middle East. East Mediterr Health J. 2021;27(4):381-389. https://doi.org/10.26719/2021.27.4.381

Received: 03/05/20; accepted: 03/02/21

Copyright $\odot$ World Health Organization (WHO) 2021. Open Access. Some rights reserved. This work is available under the CC BY-NC-SA 3.0 IGO license (https://creativecommons.org/licenses/by-nc-sa/3.0/igo).

\section{Introduction}

In 2018, there were an estimated 160 ooo new human immunodeficiency virus (HIV) infections globally among children aged $<15$ years $(1)$, which was a remarkable reduction from $>400000$ cases in 2000 (2). This achievement, arguably one of the greatest public health accomplishments in recent years, was the result of increasing prevention of mother-to-child transmission (MTCT) of HIV globally from 1\% in 2000 to $80 \%$ in 2017 (2) and 92\% in 2018 (1).

The World Health Organization (WHO) recommends 4 integrated strategies for reduction of paediatric HIV cases. They include prevention of HIV in women of childbearing age, family planning, prevention of MTCT, and care and support for HIV-infected mothers and their infants and families (3). Components of the third strategy include highly active antiretroviral therapy (HAART) during pregnancy (4), a planned prelabour caesarean section (CS) if indicated (5), avoidance of breastfeeding (6), and a short course of antiretrovirals for the infants (7). A recent systematic review showed that prelabour CS did not result in a significant reduction of MTCT of HIV in the context of viral suppression. Besides, prelabour CS was associated with a 3 -fold increase in maternal morbidity compared with vaginal delivery (8). WHO recommends that prelabour CS should not be routinely recommended to women living with HIV, and the decision about the mode of delivery should balance the potential risks and benefits for both mothers and infants (9). The risk of MTCT of HIV can be reduced to < $1 \%$ if preventive interventions are applied effectively (4).

A crucial step in prevention of MTCT of HIV is identifying the seropositive status of pregnant women. Antenatal screening for HIV, a partnership between the National AIDS Programme (NAP) and Department of Maternal and Child Health at the Ministry of Health, was introduced in Oman in July 2009 (10). The policy recommends routinely offering HIV and syphilis testing to all pregnant women, attending public and private institutions, as part of booking blood tests. Women who have not booked tests and those without a documented HIV test in their antenatal records should have rapid HIV testing at labour. All HIV-positive pregnant women are counselled and referred to a secondary care facility where they are managed by a multidisciplinary team consisting 
of specialists in infectious diseases, obstetrics and paediatrics (11). The coverage of HIV antenatal screening in Oman has been consistently high (> 95\%) over recent years (12), and in 2018, 97.24\% (86 534/88 990) of pregnant women who attended at least 1 antenatal visit were screened for HIV (13).

In January 2016, NAP in Oman introduced a package of interventions, including capacity building for HIV service providers and the development of clinical care pathways to improve the quality of HIV services in the country. The impact of such interventions on the cascade of HIV care in Oman has recently been reported $(14,15)$. This study reports the impact of these interventions, along with other specific actions taken by NAP targeting the prevention of MTCT of HIV, on the rate of vertical HIV transmission between January 2016 and December 2019. We also describe the virological and obstetric outcomes for HIV-infected pregnant women who delivered in the same period.

\section{Methods}

\section{Study setting}

The geography, demographics and HIV prevalence/services in Oman setting have been described elsewhere $(14,15)$. The prevalence of HIV in Oman is low (1). The first case was diagnosed in 1984, and by December 2018, 3060 HIV/AIDS cases were reported to NAP; 1566 (51.2\%) of whom were alive (16). Fourteen centres provide free access to HIV treatment and care (11). The country has robust and accessible primary health care, and antenatal care coverage and institutional delivery have been around $99.6 \%$ over the last 10 years (12).

\section{Study population}

We studied HIV-infected pregnant women who delivered between January 2016 and December 2019. Women with miscarriages and pregnancy terminations were excluded.

\section{Interventions}

(1) Development of capacity building and clinical care pathways is described elsewhere $(14,15)$. In summary, the capacity building activities included hands-on training followed by ongoing clinical mentoring for HIV doctors, nurses, counsellors and pharmacists. Streamlined care pathways were developed for new HIV diagnosis, ART initiation, ART switching, treatment failure and retention in care. The pathways recommended that newly diagnosed patients should receive effective counselling and pre-ART preparation. Patients were seen at 2,4,8 and 12 weeks after initiation or modification of ART for adherence support, management of adverse effects, and laboratory monitoring. A nurse or pharmacist contacted patients who missed their clinic visits to reschedule appointments and ensure continuity of ART supply. (2) Case review of HIV vertical transmissions and near misses by NAP and MCH teams. (3) Experienced HIV counsellors, at the secondary care level, gave the initial post-test counselling for newly diagnosed HIV-positive pregnant women instead of the primary health care team. (4) Linkage into and retention in care pathways was developed with a strong emphasis on pregnant women.

\section{Data sources}

Patients were identified from the NAP database. NAP collects cohort data for all people diagnosed with HIV in Oman as part of the national HIV surveillance programme. HIV treatment centres send NAP notifications of newly diagnosed cases and annual follow-up clinical information.

\section{Data collection}

Data collected included maternal demographics, HIV characteristics [HIV risk, reason for HIV test, baseline CD4 count and HIV viral load (measurements closet to HIV diagnosis)] and ART details [protease inhibitor (PI)-based HAART, non-nucleoside reverse transcriptase inhibitor (NNRTI)-based HAART and integrase-inhibitor-based HAART]. We also recorded hepatitis B and C virus coinfection status and obstetric characteristics: gravidity, parity, gestational age at HIV diagnosis and first HIV clinic appointment for newly diagnosed mothers, and gestational age at first HIV clinic appointment after conception in previously known HIV cases. Social data included history of domestic violence, financial problems and housing issues during pregnancy. Data on key outcomes of interest were also collected, such as self-reported adherence during pregnancy, HIV viral load at or near to delivery (categorized as < 50, 51-399, 400-999 and $\geq 1000$ copies/ml), mode of delivery, gestational age at delivery, birth weight (categorized as $>3 \mathrm{~kg}, 2.5-3.0 \mathrm{~kg}$ and $<2.5 \mathrm{~kg}$ ) and MTCT of HIV. Adherence was categorized as excellent, good and poor if the mother reported taking $100 \%, \geq 95 \%$ but $<100 \%$, and $<95 \%$, respectively. Mode of delivery was categorized as spontaneous vaginal delivery, instrumental vaginal delivery and CS. Gestational age at delivery was grouped as $\geq 37,35-36,32-34$ and < 32 weeks. The rate of MTCT of HIV was calculated as the number of HIV-positive infants divided by the number of infants born to HIV-infected pregnant women. Infants were considered uninfected if the HIV polymerase chain reaction was negative after 3 months of age or if the HIV antibody test was negative after 18 months of age.

Data were collected using a standardized proforma, which was produced by NAP and sent to the respective HIV clinics. Data were collated centrally and entered into Microsoft Excel Office 2016 for analysis. Ethical approval was not sought as this study was a clinical audit, and all data variables were collected routinely as a standard of care.

\section{Results}

We identified 124 pregnancies in 2016-2019. Due to incomplete reporting, 14 pregnancies in 2019 were excluded from further analysis. Table 1 shows the maternal characteristics. There were 110 pregnancies in 94 women. The median age was 32 years [interquartile range (IQR) 25-34 years]. The majority $(75.3 \%, 61 / 81)$ of women were diagnosed with HIV infection from routine antenatal screen- 


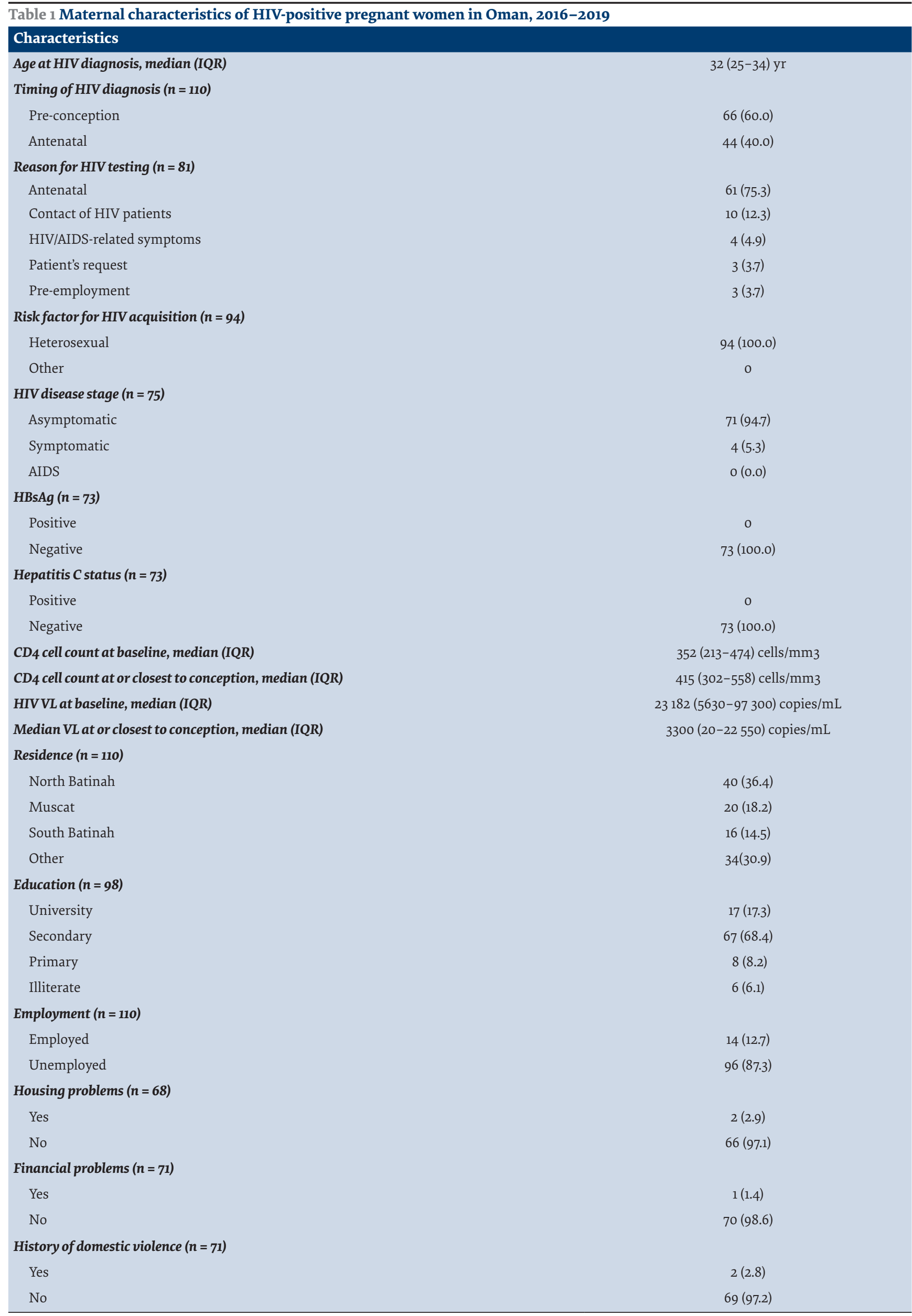

Data are $n(\%)$ unless otherwise indicated. $I Q R=$ interquartile range; $\mathrm{VL}=$ viral load. 
ing, with $60 \%(66 / 110)$ of pregnancies occurring in women who knew their HIV status at conception. Seventy-one of 75 (94.7\%) women were asymptomatic at diagnosis. The median $\mathrm{CD}_{4}$ count at baseline and conception was 352 cells $/ \mathrm{mm}^{3}$ (IQR, 213-474 cells $/ \mathrm{mm}^{3}$ ) and 415 cells $/ \mathrm{mm}^{3}$ (IQR, 302-558 cells $/ \mathrm{mm}^{3}$ ), respectively. Eighty-four of 98 (85.7\%) pregnancies were in women with at least secondary education. Fourteen of 110 (12.7\%) pregnant women were employed. History of domestic violence was reported in 2 of $71(2.8 \%)$ pregnant women.

The obstetric details are shown in Table 2 . The median number of previous pregnancies was $1(0-3)$, and $35.4 \%$ (35/99) were primigravid. The median gestational age at booking and first HIV clinic attendance, in new cases was 9 weeks. CS was the mode of delivery in half of 104 pregnancies. Preterm delivery (<37 weeks) occurred in 24 of $99(21.2 \%)$ of deliveries. Birth weight was documented in 88 infants, and 14 (15.9\%) had low birth weight $(<2.5$ $\mathrm{kg})$.

Table 3 illustrates the details of antiretroviral use in mothers and infants. The most used ART during pregnancy was NNRTI-based HAART (57.3\%, 63/110), followed by PI-based HAART (29.1\%, 32/110). Self-reported adherence to ART during pregnancy was excellent, good and poor in $74.2 \%(49 / 66), 13.6 \%$ (9/66) and $12.1 \%$ $(8 / 66)$, respectively. Five women were not on ART during pregnancy. Three of them knew their HIV status prior to the index pregnancy and had a longstanding history of disengagement with HIV services. One woman had no antenatal care and was diagnosed with HIV at delivery. The fifth woman was diagnosed with HIV antenatally, but neither the patient nor the medical team attending her labour knew her HIV status, and her infant was infected. The HIV viral load at or closest to delivery was

\begin{tabular}{|c|c|}
\hline Characteristics & \\
\hline \multicolumn{2}{|l|}{ Parity $(n=109)$} \\
\hline Primigravida & $35(35.4)$ \\
\hline Gravida 2 & $24(24.2)$ \\
\hline Gravida 3 & $12(12.1)$ \\
\hline Gravida $>3$ & $38(38.3)$ \\
\hline No. of previous pregnancies, median (IQR) & $1(0-3)$ \\
\hline Gestational age at booking first midwife appointment, median (IQR) & $9(6-14) \mathrm{wk}$ \\
\hline Gestational age at first HIV appointment in new cases, median (IQR) & $9(7-15) \mathrm{wk}$ \\
\hline Gestational age at first HIV clinic attendance after conception in old cases, median (IQR) & $12(15-23)$ \\
\hline \multicolumn{2}{|l|}{ Mode of delivery $(n=104)$} \\
\hline Spontaneous vaginal delivery & $49(47.1)$ \\
\hline Instrumental vaginal delivery & $3(2.9)$ \\
\hline Caesarean section & $52(50.0)$ \\
\hline Gestational age at delivery, median (IQR) & $38(37-38) \mathrm{wk}$ \\
\hline \multicolumn{2}{|l|}{ Gestational age at delivery ( $n=99)$} \\
\hline$<32 \mathrm{wk}$ & $2(2.0)$ \\
\hline $32-34 \mathrm{wk}$ & $7(7.1)$ \\
\hline $35-36 \mathrm{wk}$ & $12(12.1)$ \\
\hline$\geq 37 \mathrm{wk}$ & $78(78.8)$ \\
\hline \multicolumn{2}{|l|}{ Year of delivery $(n=110)$} \\
\hline 2016 & $32(29.1)$ \\
\hline 2017 & $27(24.5)$ \\
\hline 2018 & $33(30.0)$ \\
\hline 2019 & $18(16.4)$ \\
\hline Live birth $(n=110)$ & $108(98.2)$ \\
\hline \multicolumn{2}{|l|}{ Birth weight $(\mathrm{n}=88)$} \\
\hline$>3.0 \mathrm{~kg}$ & $42(47.7)$ \\
\hline $2.5-3.0 \mathrm{~kg}$ & $32(36.4)$ \\
\hline$<2.5 \mathrm{~kg}$ & $14(15.9)$ \\
\hline
\end{tabular}

Data are $n(\%)$ unless otherwise indicated. IQR = interquartile range. 


\begin{tabular}{|c|c|}
\hline Characteristics & \\
\hline \multicolumn{2}{|l|}{ On HAART at conception $(n=110)$} \\
\hline Yes & $64(57.2)$ \\
\hline No & $46(41.8)$ \\
\hline \multicolumn{2}{|l|}{ Type of ART during pregnancy $(n=110)$} \\
\hline NNRTI-based HAART & $63(57.3)$ \\
\hline PI-based HAART & $32(29.1)$ \\
\hline INSTI-based HAART & $10(9.1)$ \\
\hline None & $5(4.5)$ \\
\hline \multicolumn{2}{|l|}{ Adherence to ART during pregnancy $(n=66)$} \\
\hline Excellent & $49(74.2)$ \\
\hline Good & $9(13.6)$ \\
\hline Poor & $8(12.1)$ \\
\hline Median VL at or closest to delivery, median (IQR) & $20(20-139)$ copies/ml \\
\hline \multicolumn{2}{|l|}{ HIV VL at or closest to delivery $(n=98)$} \\
\hline Undetectable & $65(66.3)$ \\
\hline 51-399 copies/ml & $15(15.3)$ \\
\hline 400-999 copies/ml & $2(2.0)$ \\
\hline$\geq 1000$ copies $/ \mathrm{ml}$ & $16(16.3)$ \\
\hline \multicolumn{2}{|l|}{ Intrapartum ZDV $(n=101)$} \\
\hline Yes & $88(87.1)$ \\
\hline No & $13(12.9)$ \\
\hline \multicolumn{2}{|l|}{ ART received by infants $(n=102)$} \\
\hline ZDV monotherapy & $90(88.2)$ \\
\hline HAART & $11(10.8)$ \\
\hline None & $1(1.0)$ \\
\hline \multicolumn{2}{|l|}{ Adherence to infant's ART ( $n=68$ ) } \\
\hline Excellent & $46(67.6)$ \\
\hline Good & $20(29.4)$ \\
\hline Poor & $2(3.0)$ \\
\hline \multicolumn{2}{|l|}{ Infant's HIV status ( $n=99$ ) } \\
\hline Negative & $98(99.0)$ \\
\hline Positive & $1(1.0)$ \\
\hline
\end{tabular}

Data are $n(\%)$ unless otherwise indicated. ART = antiretroviral therapy; HAART = highly active antiretroviral therapy; INSTI = integrase inhibitor; $I Q R=$ interquartile range; $P I=$ protease inhibitor; NNRTI = non-nucleoside reverse transcriptase inhibitors; $\mathrm{VL}=$ viral load; $\mathrm{ZDV}=$ zidovudine.

$<400$ copies/ml in $81.6 \%(80 / 98)$ of pregnancies, with a median viral load of 20 copies/ml (IQR, 20-139 copies/ $\mathrm{ml})$. Intrapartum zidovudine was used in the majority $(87.1 \%, 88 / 101)$ of pregnancies. Similarly, most $(88.2 \%$, 90/102) infants received zidovudine monotherapy.

HIV testing data were missing for 9 babies; 5 of whom were born towards the end of 2019. The rate of MTCT of HIV was $1 \%(1 / 99)$. For this infant, the mother was diagnosed with HIV late in pregnancy, when she attended antenatal care at around 31weeks gestation on 25 February 2016 at her local primary health centre. She missed her subsequent antenatal clinic appointments, and the medical team were unable to inform her of the
HIV diagnosis. She had complex social circumstances and was recalled to the clinic on several occasions without success. She delivered on 6 April 2016 without any HIV interventions in place. She subsequently attended the health centre for postnatal follow-up on 18 May 2016 when she was informed of her HIV diagnosis and urgently referred to the HIV clinic. The viral load of her infant from that day was 8657676 copies $/ \mathrm{ml}$. The mother's baseline viral load and CD4 count were 17921 copies $/ \mathrm{ml}$ and 474 cells $/ \mathrm{mm}^{3}$, respectively.

\section{Discussion}

Our data show that CS was the most common (50\%) mode of delivery. The preterm labour and low birth weight rates 
were $21.2 \%$ and $15.9 \%$, respectively. The ART coverage during pregnancy was $95.5 \%$, with most $(87.8 \%)$ women reporting excellent or good adherence. The majority (81.6\%) of women achieved HIV viral load < 400 copies/ml at or near delivery. Almost all infants (99\%) were given prophylactic antiretrovirals. The most important outcome of our study is the low (1\%) rate of MTCT of HIV.

We observed a higher rate of CS in our study compared to that in the general population in Oman (50\% vs 19.4\%) (12). This is partly due to the use of CS as an intervention to reduce the risk of MTCT of HIV when the maternal HIV viral load is > 400 copies $/ \mathrm{ml}$ (5). The low birth weight rate in our cohort was also higher than the national average (15.9\% vs $11.6 \%$ ) (12). Islam et al. recently reported $9.7 \%$ preterm labour in 534 singleton live births at a tertiary hospital in Muscat (17), which is lower than the $21.2 \%$ in our study. HIV infection per se and antiretrovirals can partly explain the higher rates of adverse neonatal complications observed in our cohort (18-21). However, our findings of higher rates of preterm delivery, low birth weight and CS are consistent with previous studies conducted among HIV-infected pregnant women (22-29). For instance, a recent large population-based cohort study in the United States of America showed that pregnant HIV-positive women had a greater likelihood of CS than their HIV-negative counterparts (23). Moreover, neonates born to HIV-infected women were at higher risk of prematurity and intrauterine growth restriction (23). The British HIV Association national audit of deliveries in 2013 and 2014 showed that CS occurred in 53.2\% (719/1349) of pregnancies (24). Also, 11-year data from a large German HIV cohort showed that CS and preterm labour rates were $89.6 \%$ (296/330) and 37\% (122/330), respectively (25).

The virological outcomes in our patients concurred with those achieved in previous studies (25-29). HIV viral load < 400 copies/ml at or near delivery in our study was similar to that reported in a German cohort $(81.6 \%$ vs $85 \%$ ) (25). Moreover, the HIV MTCT rate in our study was low (1\%) and comparable to levels reported in the United Kingdom of Great Britain and Northern Ireland and Germany $(5,25)$. Data about the management of HIVinfected pregnant women in the Middle East and North Africa (MENA) are scarce. A report of 40 pregnancies in HIV-positive women from Saudi Arabia showed that HIV viral load < 1000 copies at delivery and CS occurred in $77.5 \%(31 / 40)$ and $70 \%(28 / 40)$, respectively, with all 39 infants testing negative for HIV infection (29).

In January 2016, the NAP in Oman introduced interventions to build the capacity of HIV service providers, which have resulted in remarkable improvements in all aspects of the cascade of HIV care from linkage into care to viral suppression $(14,15)$. This positive impact was noted in all HIV patients' groups, including pregnant women. HIV infection remains a stigmatized and socially complex disease, particularly in the MENA Region. Therefore, the provision of psychological support to newly diagnosed HIV-positive pregnant women as they adjust to their diagnosis and get ready to start ART is crucial. Our care pathways support patients, including pregnant women as they go through the HIV care continuum from diagnosis to viral load suppression. The face-to-face, multisession adherence support after initiating ART could explain, in part, the favourable clinical outcomes that we observed among our cohort (30).

The case review of HIV vertical transmission (31) was invaluable in identifying gaps in services and informing quality improvement initiatives. This exercise identified 3 main problems in the continuum of care for pregnant women, particularly linkage into care. Firstly, the high turnover among primary health care staff, coupled with the limited exposure to HIV cases resulted in poor quality post-test counselling and support for newly diagnosed HIV-positive women in antenatal clinics. Secondly, we identified significant delays of up to 3 weeks in referring new cases to HIV treatment centres while waiting for confirmation of the initially reactive HIV test. Thirdly, the lack of a multidisciplinary approach and escalation mechanisms when dealing with poor maternal compliance with prevention of MTCT interventions, such as missing appointments and declining ART during pregnancy. To rectify these problems, post-test counselling for newly diagnosed HIV-positive pregnant women is now given by experienced HIV counsellors at the secondary instead of primary health care level. Linkage into and retention in care pathways was developed with a strong emphasis on pregnant women. In this pathway, the gestational age of pregnancy determines the urgency of action; for instance, any new diagnosis or loss to follow-up in the second/third trimester is considered a medical emergency. In such a scenario, the case should be discussed with the director of communicable diseases, child protection team and maternal and child health coordinator in the province. The case should also be discussed with the NAP team. This initiative has averted several potential cases of MTCT of HIV since 2016. The HIV-infected infant in our study was born in April 2016 and this was attributed to failure to link the mother into HIV care. Of note, 3.5\% (4/115) of the infants born to HIV-positive pregnant women in Oman in 2012-2015 were HIV-infected (Ministry of Health, personal communication). All the four cases were due to poor adherence to ART and disengagement from HIV services during the index pregnancy.

Limitations of our study include those inherent to any retrospective design. Documentation bias and missing data may mean that point estimates were underestimated. It is possible that some of the eligible pregnancies in the study period were not included in the analysis if the NAP was not notified of the pregnancy. This is particularly relevant for pregnant women who knew their HIV status before conception as NAP solely relies on notification from HIV treatment centres. As for the women diagnosed with HIV during pregnancy, NAP is notified by the central laboratory, Department of Maternal and Child Health and HIV clinics. Another limitation was that it was not possible to generalize our findings to other populations due to the small size of our cohort. However, to our knowledge, this was the first 
nationwide study that described pregnancy outcomes in HIV-infected women in the MENA Region.

In 2015, WHO established the Global Validation Advisory Committee for Elimination of MTCT of HIV (EMTCT) (32). Since then, many countries have been validated for eliminating MTCT of HIV as a public health problem (33). The validation has process and impact targets. The process indicators are populationlevel antenatal care coverage (at least 1 visit) of $\geq 95 \%$, coverage of HIV testing of pregnant women of $\geq 95 \%$, and ART coverage of HIV-positive pregnant women of $\geq 95 \%$. The impact targets are a population case rate of new paediatric HIV infections due to MTCT of $\leq 50$ per 100 ooo live births and an HIV MTCT rate of < $2 \%$ (4-year cumulative data are required for low prevalence countries such as Oman). Oman meets both the process and impact criteria for EMTCT of HIV validation.

To conclude, the obstetric and virological outcomes for HIV-infected pregnant women delivered in 2016-2019 were favourable. The NAP interventions, introduced in 2016, have built on the success of the HIV antenatal screening programme and closed the gaps in the continuum of HIV care for pregnant women, paving the way for eliminating MTCT of HIV in Oman. The country is now in the process of finalizing application of the WHO EMTCT.

Funding: None.

Competing interests: None declared.

\section{Élimination de la transmission mère-enfant du VIH à Oman : un exemple de réussite au Moyen-Orient}

\section{Résumé}

Contexte: En janvier 2016, le Programme national de lutte contre le sida à Oman a mis en place un ensemble d'interventions, comprenant le renforcement des capacités des prestataires de services, afin d'améliorer la qualité des services de lutte contre le VIH.

Objectifs : Signaler l'impact de ces interventions sur le taux de transmission verticale du VIH au cours de la période comprise entre janvier 2016 et décembre 2019. Nous décrivons également les résultats virologiques et obstétricaux pour les femmes enceintes touchées par le VIH.

Méthodes : Il s'agissait d'un examen des dossiers médicaux, notifiés au Programme national de lutte contre le sida de 2016 à 2019, pour 94 femmes enceintes séropositives (âge médian : 32 ans; intervalle interquartile : 25-34 ans).

Résultats : Il y avait 110 grossesses chez 94 femmes. La majorité (75,3\%,61/81) des femmes ont reçu un diagnostic d'infection par le VIH lors du dépistage prénatal systématique, et $60 \%(66 / 110)$ des grossesses se sont produites chez des femmes qui connaissaient leur statut sérologique au moment de la conception. La césarienne était le mode d'accouchement le plus courant (50\%). Les taux de travail prématuré et de faible poids de naissance étaient respectivement de $21,2 \%$ et $15,9 \%$. La couverture antirétrovirale pendant la grossesse était de 95,5 \%, la plupart des femmes (87,8 \%) signalant une excellente ou une bonne observance. La majorité (81,6 \%) des femmes ont atteint une charge virale VIH inférieure à 400 copies/ml à l'accouchement ou à proximité. Presque tous les nourrissons (99\%) ont reçu des antirétroviraux prophylactiques. Le taux de transmission mère-enfant du VIH était de $1 \%$.

Conclusion: Les résultats obstétricaux et virologiques des femmes enceintes séropositives ayant accouché entre 2016 et 2019 étaient favorables, avec un faible taux de transmission mère-enfant du VIH. Oman finalise actuellement l'application de la validation de l'élimination de la transmission mère-enfant du VIH par l'Organisation mondiale de la Santé.

$$
\begin{aligned}
& \text { القضاء على انتقال فيروس العوز المناعي البشري من الأم إلى الطفل في عُمان: قصة نجاح من الشرق الأوسط }
\end{aligned}
$$

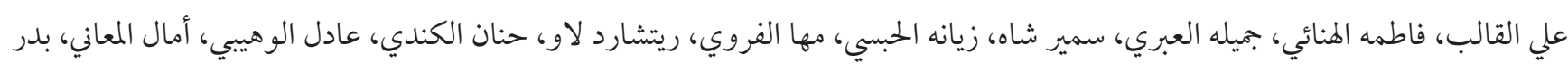

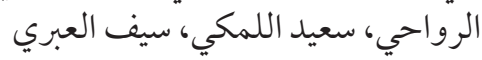

$$
\begin{aligned}
& \text { الخالاصة }
\end{aligned}
$$

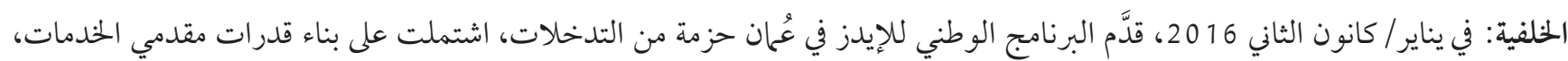

$$
\begin{aligned}
& \text { بغرض تحسين جودة الخذمات الخاصة بفيروس الني العوز المناعي البشري. }
\end{aligned}
$$

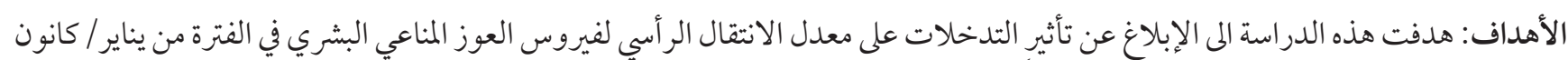

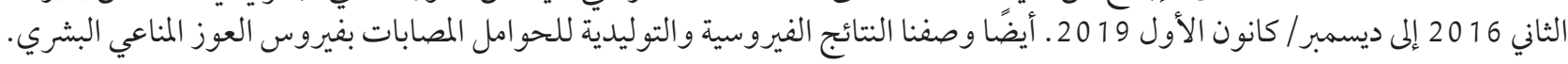

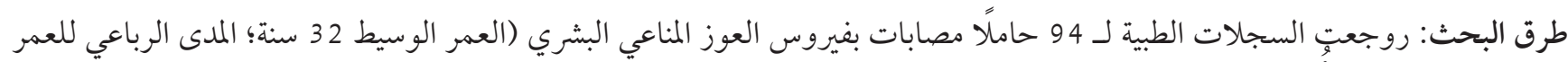

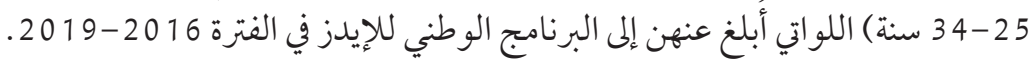




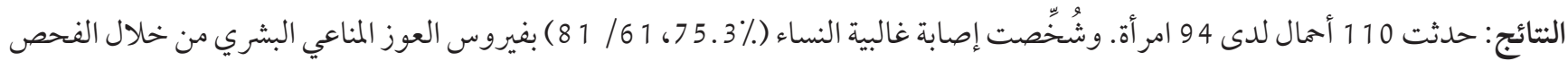

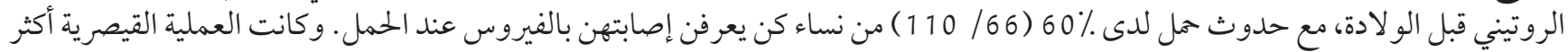

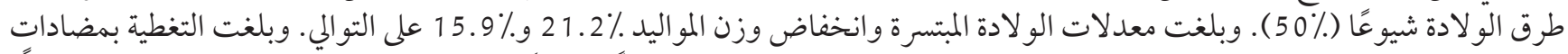

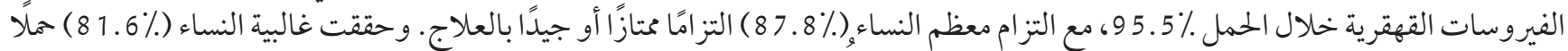

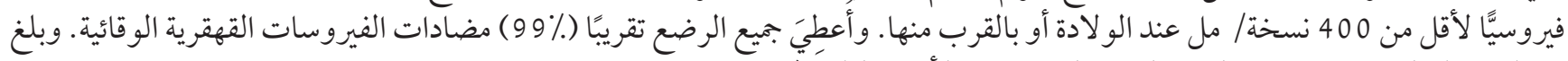

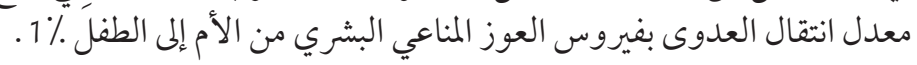

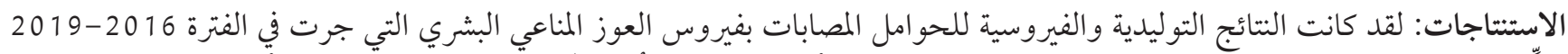

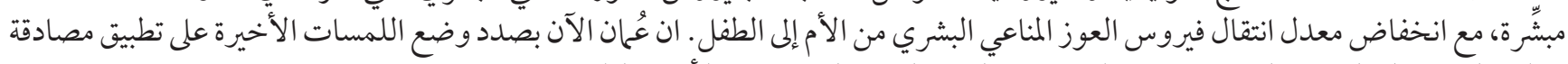

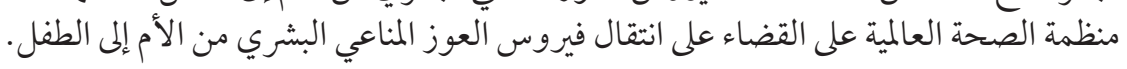

\section{References}

1. UNAIDS data 2019. Geneva: UNAIDS; 2019 (https://www.unaids.org/sites/default/files/media_asset/2019-UNAIDS-data_en.pdf, accessed 1 April 2021).

2. Miles to go: global AIDS update 2018. Geneva: UNAIDS; 2018 (https://www.unaids.org/sites/default/files/media_asset/miles-togo_en.pdf, accessed 1 April 2021).

3. Prevention of HIV in infants and young children. Review of evidence and WHO's activities. Geneva: World Health Organization; 2002 (https://www.who.int/hiv/pub/mtct/review_2002/en/, accessed 1 April 2021).

4. Cooper ER, Charurat M, Mofenson L, Hanson IC, Pitt J, Diaz C et al. Combination antiretroviral strategies for the treatment of pregnant HIV-1-infected women and prevention of perinatal HIV-1 transmission. J Acquir Immune Defic Syndr. 2002 Apr 15;29:484-94. https://doi.org/10.1097/00126334-200204150-00009 PMID:11981365

5. Townsend CL, Byrne L, Cortina-Borja M, Thorne C, de Ruiter A, Lyall H et al. Earlier initiation of ART and further decline in mother-to-child HIV transmission rates, 2000-2011. AIDS. 2014 Apr 24;28(7):1049-57. https://doi.org/10.1097/ QAD.0000000000000212 PMID:24566097

6. Nduati R, John G, Mbori-Ngacha D, Richardson B, Overbaugh J, Mwatha A et al. Effect of breastfeeding and formula feeding on transmission of HIV-1: a randomized clinical trial. JAMA. 2000 Mar 1;283(9):1167-74. https://doi.org/10.1001/jama.283.9.1167 PMID:10703779

7. Connor EM, Sperling RS, Gelber R, Kiselev P, Scott G, O'Sullivan MJ et al. Reduction of maternal-infant transmission of human immunodeficiency virus type 1 with zidovudine treatment. Pediatric AIDS Clinical Trials Group Protocol 076 Study Group. N Engl J Med. 1994 Nov 3;331(18):1173-80. https://doi.org/10.1056/NEJM199411033311801 PMID:7935654

8. Kennedy CE, Yeh PT, Pandey S, Betran AP, Narasimhan M. Elective cesarean section for women living with HIV: a systematic review of risks and benefits. AIDS. 2017 Jul 17;31(11):1579-91. https://doi.org/10.1097/QAD.0000000000001535 PMID:28481770

9. Consolidated guideline on sexual and reproductive health and rights of women living with HIV. Geneva: World Health Organization; 2017 (https://apps.who.int/iris/bitstream/handle/10665/254885/9789241549998-eng.pdf;jsessionid=B0695011DC1406CC9C349F2B52A8CB16?sequence=1, accessed 1 April 2021).

10. HIV testing in pregnancy, standard operative procedure guidelines, 2nd edition. Department of Maternal and Child Health, Ministry of Health, Oman; 2011.

11. HIV management in Oman. A guide for health care workers, 3rd edition. National AIDS Program; Department of Communicable Diseases; Directorate General for Disease Surveillance and Control; Ministry of Health; 2015 (https://www.moh.gov.om/documents/236878/o/A+guide+for+health+care+workers/2ef88339-1211-43b3-ad4a-8b326bc3c9a3, accessed 1 April 2021).

12. Annual Health Reports 2011-2018 [website]. Sultanate of Oman Ministry of Health (https://www.moh.gov.om/en/web/statistics/ annual-reports, accessed 1 April 2021).

13. Annual Health Report 2018. Sultanate of Oman Ministry of Health; 2018 (https://www.moh.gov.om/documents/274609/3563447//l 383080f3-a72e-5c05-fdo9-c7b5fb2c985b, accessed 1 April 2021).

14. Elgalib A, Shah S, Al-Habsi Z, Al-Fouri M, Al-Sawafi H, Al-Noumani J et al. HIV viral suppression in Oman: encouraging progress toward achieving the United Nations 'third 90'. Int J Infect Dis. 2018 Jun;71;94-9. https://doi.org/10.1016/j.ijid.2018.04.795

15. Elgalib A, Shah S, Al-Habsi Z, Al-Fouri M, Lau R, Al-Kindi H et al. The cascade of HIV care in Oman, 2015-2018: a population-based study from the Middle East. Int J Infect Dis. 2020 Jan;90;28-34. https://doi.org/10.1016/j.ijid.2019.09.017 PMID:31568859

16. Elgalib A, Shah S, Al-Wahaibi A, Al-Habsi A, Al-Fouri A, Lau R et al. The Epidemiology of HIV in Oman, 1984-2018: a nationwide study from the Middle East. J Epidemiol Glob Health. 2020 Sep;10(3):222-9. https://doi.org/10.2991/jegh.k.191208.001 PMID: 32954713

17. Islam MM, Al-Thihli K, Abdellatif M. Maternal and neonatal factors influencing preterm birth and low birth weight in Oman: a hospital based study. Int J Child Health Nutr. 2013;2:281-95. https://doi.org/10.6000/1929-4247.2013.02.04.2 
18. Xiao PL, Zhou YB, Chen Y, Yang MX, Song XX, Shi Y et al. Association between maternal HIV infection and low birth weight and prematurity: a meta-analysis of cohort studies. BMC Pregnancy Childbirth. 2015 Oct 8;15:246. https://doi.org/10.1186/s12884-0150684-z PMID:26450602

19. Aaron E, Bonacquisti A, Mathew L, Alleyne G, Bamford LP, Culhane JF. Small-for- gestational-age births in pregnant women with HIV, due to severity of HIV disease, not antiretroviral therapy. Infect Dis Obstet Gynecol. 2012;2012:135030 https://doi. org/10.1155/2012/ 135030 PMID:22778533

20. Short CE, Douglas M, Smith JH, Taylor GP. Preterm delivery risk in women initiating antiretroviral therapy to prevent HIV mother-to-child transmission. HIV Med 2014 Apr; 15(4):233-8. https://doi.org/10.1111/hiv.12083 PMID:24025074

21. Li N, Sando MM, Spiegelman D, Hertzmark E, Liu E, Sando D et al. Antiretroviral therapy in relation to birth outcomes among HIV-infected women: a cohort study. J Infect Dis. 2016 Apr 1;213(7):1057-64. https://doi.org/10.1093/infdis/jiv389 PMID:26265780

22. Carey L, Desouza C, Moorcroft A, Elgalib A. Pregnancy outcomes of women with HIV in a district general hospital in the UK. J Obstet Gynaecol. 2018 Aug;38(6):777-80. https://doi.org/10.1080/01443615.2017.1416598 PMID:29526132

23. Arab K, Spence AR, Czuzoj-Shulman N, Abenhaim HA. Pregnancy outcomes in HIV-positive women: a retrospective cohort study. Arch Gynecol Obstet. 2017 Mar;295(3):599-606. https://doi.org/10.1007/s00404-016-4271-y PMID:28097445

24. Raffe S, Curtis H, Tookey H, Peters H, Freedman A, Gilleece Y. UK national clinical audit: management of pregnancies in women with HIV. BMC Infect Dis. 2017 Feb 20;17(1):158. https://doi.org/10.1186/s12879-017-2255-6 PMID:28219333

25. Reitter A, Stücker AU, Linde R, Königs C, Knecht G, Herrmann E et al. Pregnancy complications in HIV-positive women: 11-year data from the Frankfurt HIV Cohort. HIV Med. 2014 Oct;15(9):525-36. https://doi.org/10.1111/hiv.12142 PMID:24602285

26. Elgalib A, Hegazi A, Samarawickrama A, Roedling S, Tariq S, Draeger E, et al. Pregnancy in HIV-infected teenagers in London. HIV Med. 2011 Feb;12(2):118-23. https://doi.org/10.1111/j.1468-1293.2010.00878.x

27. Momplaisir FM, Brady KA, Fekete T, Thompson DR, Diez Roux A, Yehia BR. Time of HIV diagnosis and engagement in prenatal care impact virologic outcomes of pregnant women with HIV. PLoS One. 2015 Jul 1;10(7):e0132262.

28. https://doi.org/10.1371/journal.pone.0132262 PMID:26132142

29. Agmon-Levin N, Elbirt D, Asher I, Morais SS, Lajos GJ, Silva JL et al. Prevention of human immunodeficiency virus mother-tochild transmission in Israel. Int J STD AIDS. 2009 Jul;20(7):473-6. https://doi.org/10.1258/ijsa.2008.008392 PMID:19541889

30. Fageeh WMK. Presentation and pregnancy outcome of HIV-positive women in Jeddah, Saudi Arabia. Int J Gynaecol Obstet. 2011 Jun;113(3):239-40. https://doi.org/10.1016/j.ijgo.2010.12.012 PMID:21457983

31. Mbuagbaw L, Sivaramalingam B, Navarro T, Hobson N, Keepanasseril A, Wilczynski N et al. Interventions for enhancing adherence to antiretroviral therapy (ART): a systematic review of high-quality studies. AIDS Patient Care STDS. 2015 May;29(5):248-66. https://doi.org/10.1089/apc.2014.0308 PMID:25825938

32. FIMR/HIV pilot project and lessons learned. University of Nebraska Medical Center: CityMatCH; 2009. http://www.fimrhiv.org/ documents/FIMRHIV.pdf, accessed 1 April 2021).

33. Elimination of mother-to-child transmission (EMTCT) of HIV and syphilis. Global guidance on criteria and processes for validation. Geneva: World Health Organization; 2014 (https://www.who.int/reproductivehealth/publications/rtis/9789241505888/en/, accessed 1 April 2021).

34. Thailand, Belarus and Armenia eliminate mother-to-child transmission of HIV [website]. Geneva: World Health Organization (https://www.who.int/hiv/mediacentre/news/emtct-validation-2016/en/, accessed 1 April 2021). 